of the fracture. Again, the Judet arthroplasty, either with a metallic or a plastic prosthesis, is no longer one that commends itself to many surgeons.

The style of writing is uneven, passages in narrative form being occasionally interrupted by verbless sentences. The author's instructions for passing examinations are unlikely to be viewed with favour by those responsible for medical education in this country, while his time-table for a rehabilitation centre, allowing 'free time' from I 900 hours to I 900 hours, is likely to meet with a rather mixed reception from those being rehabilitated.

The idea of the book is a good one, much of the information containec' in it is useful, many references are given (though Holdsworth's work on paraplegia is not mentioned) and the standard of production is excellent. A considerable reappraisal will, however, be needed if it is to fulfil its author's expressed aims.

\section{THE PRINCIPLES AND PRACTICE OF DIATHERMY}

By B. O. ScotT, M.R.C.S., L.R.C.P., D.Phys.Med. Pp. vii +193 , with 146 illustrations. London: William Heinemann Ltd. 1957. 25s.

This book is intended for the physical medicine specialist and physiotherapist and is therefore a technical work. However, the style in which it is written is most readable and the more advanced theoretical considerations are separated from the rest of the text. There are numerous diagrams and illustrations and a useful bibliography follows each chapter.

The author has himself carried out original experimental work and writes with the authority of considerable experience of his subject.

\section{EVERYDAY PAEDIATRICS}

By B. Gans, M.D., M.R.C.P., and L. I. Norian, M.B., B.S. Pp. 216 . London: Faber and Faber. I957. I 2s. $6 \mathrm{~d}$.

There is a lot of common sense and useful information in this little book. The part by Dr. Gans, however, gives the impression that he has heard of and applied many of the new attitudes to disease in childhood without really understanding their basic reasons. For example, it is strange to see that the same doctor who calls constipation 'an AngloSaxon neurosis' advises the use of amphetamine sulphate in the treatment of enuresis! Even writing on physical illness Dr. Gans makes some rash statements: 'The practitioner is unlikely to miss a case of intussusception'; the last child your reviewer saw with an intussusception had been a puzzle to an excellent doctor for five days.

The brief section on the child and the community, by Dr. Norman, giving details of the child welfare service, is useful.

Your reviewer is sure that both the authors of this book are good at the practical task of helpinge? children and their parents, but their own personalo ways can appear misleading in point. \section{THE CLOSED TREATMENT OF COMMON:}

By John Charnley, B.Sc., M.B., F.R.C.S. Secondo edition. Pp. xii +260 , with 199 illustrations. Edinburgh: E. \& S. Livingstone Ltd. 1957. 50s.

Seven years ago Mr. Charnley published the first $\stackrel{\Phi}{\circ}$ edition of this book, written primarily for the resident casualty surgeon. Fearing that it had been ${ }^{\text {( }}$ mistaken for an elementary students' manual, he $\vec{\circ}$ has now rewritten and revised it 'at postgraduatelevel.' It is perhaps a sign of the times that he has $\vec{\omega}$ felt the need to introduce much material defending his advocacy of conservative treatment. Thus $\mathrm{a}$ o provocative new first chapter is devoted to the main 3 . features of bone repair and includes many original $\omega$ observations and theories relating to this and the role of operative intervention.

The following chapters are only slightly altered $\stackrel{\infty}{\infty}$ from the first edition and comprise the bulk and the best of the monograph. An excellent practical ando theoretical account is given of the closed treatmento of common fractures with particular emphasis the primary reduction and immobilization.

Some criticisms are possible. The unwary reader $\frac{9}{\mathbb{Q}} \mathbb{D}^{\top}$ may gain the impression that all finger fractures are treated in plaster, for the chapter with this heading is concerned entirely with the author's method of treating unstable fractures of the proximal phe $\overrightarrow{\mathbb{P}}$ anges. There is a rather light-hearted dismissal $8 \mathrm{f}$ finger stiffness due to fixation on the grounds that will always recover in time. Perhaps it would haveo been better avoided in the first place by a shorter period of immobilization.

It is regrettable that skin traction is so firmlyo condemned. With a little skill and care it is a safe $\stackrel{\mathbb{Q}}{\circ}$ and effective technique.

The index is poor.

The additions to the book have not increased its usefulness to the casualty officer. In fact, by the insertion of much which is, although thought provoking, unproven or debatable, the text has $a$ 을 generally lowered standard of reliability. Nor is it comprehensive: fractures of the clavicle and scaphoid, for example, are not described.

Nevertheless, this is a very valuable book toô study and possess. It provides pleasant, stimulating, $₹$ and in places absorbing, reading for all those 0 interested practically and theoretically in what is, after all, the most important way of treating fractures.

A.J.H.

THE FOREQUARTER AMPUTATION

By H. F. Moseley, M.A., D.M., M.Ch., F.R.C.S., О् F.A.C.S. Pp. viii +79 , with 25 illustrations ando I I plates in colour. Edinburgh: E. \& S. Livingstone Ltd. 1957. $42 \mathrm{~s}$. 
This monograph on a major mutilation is very well produced. The various surgical approaches are described in detail and the coloured diagrams are luxurious. There is an interesting chapter summarizing all the traumatic forequarter amputations which have been reported since Belchier's first case in 1737 .

\section{MODERN TRENDS IN GERIATRICS}

Edited by William Hobson, B.Sc., M.D., D.P.H.

Pp. vii +422 , with 68 illustrations. London:

Butterworth \& Co. Ltd. I956. 72s. 6d.

Like so many books on geriatrics this suffers from the fact that most of the subjects dealt with are also covered by text-books dealing with the special systems. Thus, for example, in dealing with chronic bronchitis or dermatology or gynaecology in the aged, there is bound to be a major overlap with the standard text-books. For this reason the articles dealing with subjects specifically concerned with old people in this volume are of greater interest. These include articles by Dr. Hobson on public health problems and social pathology of the aged, and statistics of the changing age distribution of the population; an article by Dr. Bourne on biological changes in ageing; one of particular value by Dr. Jordan on the normal values of biochemical data in the elderly; and one by Dr. Shelden on home care of the elderly; and another by Dr. Hobson on the employment of the elderly.

The book, like the other volumes of the series, is beautifully produced and can be read with pleasure by all interested in geriatrics. It fully maintains the high standards set by its predecessors.

\section{THE LIFE, WORK AND TIMES OF CHARLES TURNER THACKRAH}

By A. Meiklejohn. Pp. 304. Edinburgh: E. \& S. Livingstone Ltd. 1957. 25 s.

This is a facsimile reprint of the second edition of Thackrah's famous work on occupational diseases, first published in 1832 . It is preceded by a biographical essay written by Dr. Meiklejohn which gives not only a brief account of Thackrah's life but also sketches in the background of his work and provides an interesting appraisal of it.

Although Thackrah's book must obviously seem in places even amusing today, the main impression one gains from this pioneering effort in British medicine is one of respect for the enlightened attitude of its author. To quote but one example: Thackrah used extensively a simple method of estimating the vital capacity by making his patients exhale into a large graduated glass jar, inverted, and filled with water-an exact counterpart of the modern spirometer-and he even went so far as to suggest that it would be of value in the routine examination of recruits for the army. In his book he gives the vital capacity of the employees in the particular trades which he investigated.

This book will be of great interest not only to the medical historian but to all those interested in industrial health.

\section{USES OF EPIDEMIOLOGY}

By J. N. Morris, M.A., F.R.C.P., D.P.H. Pp. viii + 135. Edinburgh: E. \&. S. Livingstone Ltd. I957. I7s. 6d.

In this book Dr. Morris, who is director of the Social Medicine Research Unit of the Medical Research Council at the London Hospital, has written an essay on the subject concerning which his own work is so well known. His main purpose is to stimulate interest among undergraduates and post-graduates in the ever-broadening field of epidemiology, and in this he succeeds extremely well.

The book is copiously illustrated with line diagrams and tables and shows how much has already been done in this field, and how much more remains to be done.

The subjects range from topics of major interest such as the relationship between smoking and lung cancer and the pathogenesis of coronary artery disease, to quaint observations such as the so-called Glover Phenomenon, in which it is shown that the rate of tonsillectomy in school children in Birkenhead and the Isle of Ely is approximately one-tenth of what it is in Exeter and Oxford.

The book will certainly interest all who read it and is likely to attract recruits into this fascinating and important field.

\section{REFRESHER COURSE FOR GENERAL PRACTITIONERS}

From the British Medical Fournal, Third Collection, April 1952, to September 1953. Pp. xvii + 548, illustrated. London: British Medical Association. 1956. 25 s.

For some years now refresher course articles for general practitioners have been appearing in the British Medical Fournal: This volume is the third collection to be presented in book form. Each article has been brought up to date, and is written by a well-known authority. To increase the value of the collection, the book contains a cumulative index of the articles appearing in addition to those appearing in the present volume.

The articles in the latest collection cover a wide range of subjects, ranging from heart block to anaesthetic explosions; and from hysteria to the choice of spectacles. There can be no-one practising medicine who will not learn something of interest from this very varied collection of papers. In a short review it is impossible even to summarise, let alone criticise, the different articles. Those by Professor Dacie on haemophilia; by Dr. Gordon 